||| French Film Directors
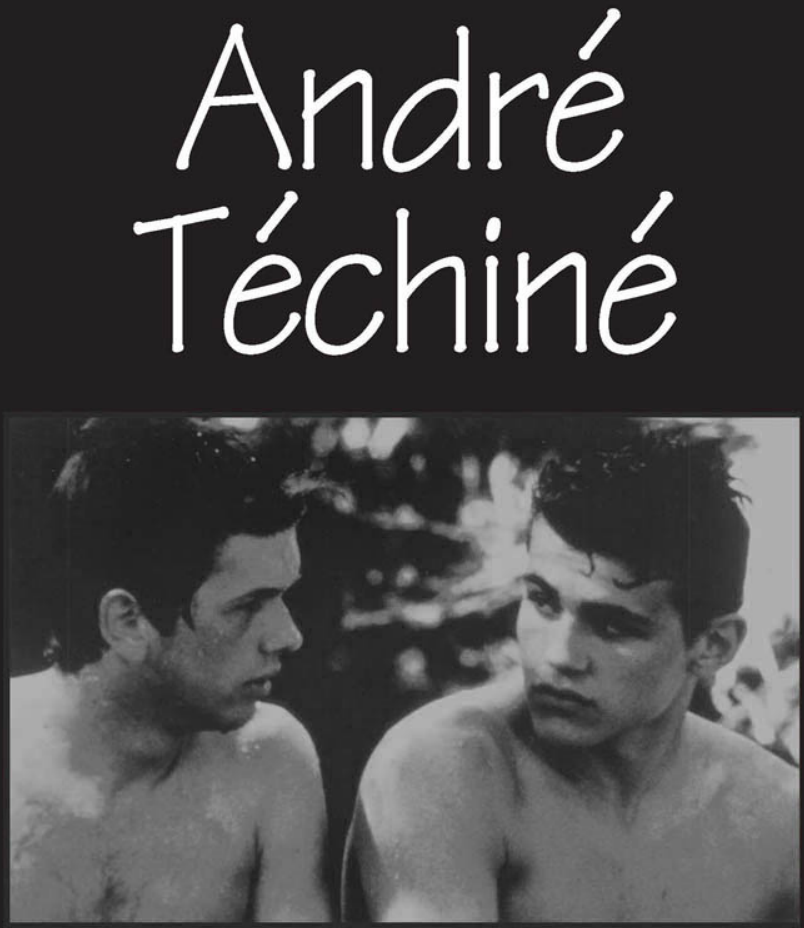

BILL MARSHALL 


\section{André Téchiné}

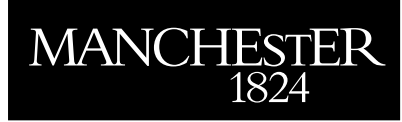

Manchester University Press 
FRENCH FILM DIRECTORS

DIANA HOLMES and ROBERT INGRAM series editors DUDLEY ANDREW series consultant

Jean-Jacques Beineix PHIL POWRIE

Luc Besson SUSAN HAYWARD

Bertrand Blier SUE HARRIS

Robert Bresson KEITH READER

Leos Carax GARIN DOWD AND FERGUS DALEY

Claude Chabrol GUY AUSTIN

Henri-Georges Clouzot CHRISTOPHER LLOYD

Jean Cocteau JAMES WILLIAMS

Claire Denis MARTINE BEUGNET

Marguerite Duras RENATE GÜNTHER

Georges Franju KATE INCE

Jean-Luc Godard DOUGLAS MORREY

Mathieu Kassovitz WILL HIGBEE

Diane Kurys CARRIE TARR

Patrice Leconte LISA DOWNING

Louis Malle HUGO FREY

Georges Méliès ELIZABETH EZRA

Maurice Pialat MARJA WAREHIME

Alain Resnais EMMA WILSON

Jean Renoir MARTIN O'SHAUGHNESSY

Eric Rohmer DEREK SCHILLING

Coline Serreau BRIGITTE ROLLET

François Truffaut DIANA HOLMES AND ROBERT INGRAM 


\section{André Téchiné}

\section{Bill Marshall}

Manchester University Press

MANCHESTER AND NEW YORK

distributed exclusively in the USA by Palgrave 
Copyright (C) Bill Marshall 2007

The right of Bill Marshall to be identified as the author of this work has been asserted by him in accordance with the Copyright, Designs and Patents Act 1988.

Published by Manchester University Press

Oxford Road, Manchester M13 9NR, UK

and Room 400, 175 Fifth Avenue, New York, NY 10010, USA

www.manchesteruniversitypress.co.uk

Distributed exclusively in the USA by

Palgrave, 175 Fifth Avenue, New York, NY 10010, USA

Distributed exclusively in Canada by

UBC Press, University of British Columbia, 2029 West Mall, Vancouver,

BC, Canada v6r $1 \mathrm{z} 2$

British Library Cataloguing-in-Publication Data

A catalogue record for this book is available from the British Library

Library of Congress Cataloging-in-Publication Data applied for

ISBN 978 ○ 719058318 hardback

EISBN 9781847791788

First published 2007

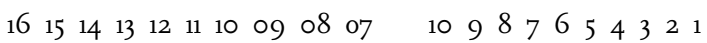

Typeset in Scala with Meta display

by Koinonia, Manchester

Printed in Great Britain

by Biddles Ltd, King's Lynn 